Yet either view, consistently applied, would provide jury trials in constructive criminal contempt cases. Under both theories, due process requires different procedural safeguards in different situations: a prosecution which fulfils the demands of due process in punishing a direct contempt may not suffice if the alleged contempt was committed out of court. ${ }^{\mathrm{x} 34}$ Justice Cardozo, expressing the majority rationale, has suggested that "... we reach a different plane of social and moral values when we pass to the privileges and immunities that have been taken over from the earlier articles of the federal bill of rights and brought within the Fourteenth Amendment by a process of absorption. These in their origin were effective against the federal government alone. If the Fourteenth Amendment has absorbed them, the process of absorption has had its source in the belief that neither liberty nor justice would exist if they were sacrificed." "r35 If this is so, then the climb of our "social and moral values" has been a slow one indeed; even the basic right of freedom of speech was only "absorbed" by the Fourteenth Amendment fifty-seven years after its adoption. ${ }^{136}$

Admittedly, the denial of jury trial in one class of contempt cases is not of the same broad sweep as the denial of free speech or a free press; perhaps it does not stand on the same plane in the scale of civil liberties. But Justice Cardozo's analysis is not exclusive. Unyielding application of the "inherent power" and "immemorial usage" doctrine by state courts has thwarted all legislative attempts to abolish summary proceedings in indirect contempts. Even if it is admitted that the "Fourteenth Amendment did not mean to imprison the States into the limited experience of the eighteenth century, ${ }^{\prime 137}$ application of the jury trial guarantee in this class of cases is preferable to the present self-imposed imprisonment into the more limited experience of the nineteenth century. A declaration by the Supreme Court that due process of law in constructive criminal contempt cases, except those charging violation of court decrees, includes trial by jury would be far better than perpetuating a useless fiction with its roots in one of the least desirable practices of the Star Chamber.

\title{
THE SEDITION TRIAL: A STUDY IN DELAY AND OBSTRUCTION
}

On January 3, 1944, a federal grand jury in Washington, D.C., returned an indictment charging thirty defendants ${ }^{x}$ with conspiracy, together with officials

${ }^{234}$ See Ex parte Oliver, I6 U.S.L. Week 4240, 4245 (1948).

x35 Palko v. Connecticut, 302 U.S. 319, 326 (1937).

${ }_{236}$ Gitlow v. New York, 268 U.S. 652 (1925).

${ }^{23}$ Justice Frankfurter concurring in Louisiana ex rel. Francis v. Resweber, 329 U.S. 459, 468 (I947); see Adamson v. California, 332 U.S. 46 (r947).

I These were Joseph E. McWilliams, George E. Deatherage, William Dudley Pelley, James True, James Edward Smythe, Lawrence Dennis, Howard Victor Broenstrupp alias Count 
of the German Reich and the Nazi Party, in violation of the Sedition Act of I940. ${ }^{2}$ Considerable publicity attended the news of the indictment. The issue, it was said, "was big: can a democracy defend itself legally?"3 Comments ranged widely from those who warned that Hitler was once considered silly" to those who spoke of an attempt "to stifle opposition to the 4 th term." O. John Rogge, the government prosecutor, emphasized that the trial was not to be a forum against conventional isolationists, but that he proposed to prove a deliberate link between views manifested by the defendants and those voiced by the Axis. ${ }^{6}$ Yet, almost three years later, in December I946, the indictment was dismissed.7 No decision was ever reached, either as to the guilt of defendants or the validity of the federal statute. So ended the Washington Sedition Trial-not with a bang but a whimper.

The indictment ${ }^{8}$ charged that the defendants had conspired to impair the loyalty of the armed services, that in furtherance of such conspiracy the defendants had distributed written and printed matter urging insubordination and disloyalty, and that this was done as part of a gigantic conspiracy with German and Nazi officials whose public program was to destroy all democratic governments and replace them by Nazi governments. By the time the defendants and their counsel began to assemble in Washington, the proceedings had been attacked as fascistic, 9 as a Jewish and Communist plot, ${ }^{\mathrm{x}}$ as destroying civil liber-

George Victor Cherepspiridovich alias Lt. Gen. Cherepspiridovich alias J. G. Francis, Robert Edward Edmonson, E. J. Parker Sage, William Robert Lyman, Jr., Garland L. Alderman, Gerald B. Winrod, Elizabeth Dilling alias Rev. Frank Woodruff Johnson, Charles B. Hudson, Elmer J. Garner, George Sylvester Viereck alias James Burr Hamilton, Prescott Freeze Dennett, Gerhard Wilhelm Kunze, Hermann Schwinn, Hans Diebel, Franz K. Ferenz, Ernest Frederick Elmhurst, Robert Noble, Ellis O. Jones, Eugene Nelson Sanctuary, David Baster, Lois de Lafayette Washburn alias T.N.T., Frank W. Clark, Peter Stahrenberg, August Klapprutt.

$=54$ Stat. 670 (I940), I8 U.S.C.A. $\$ 9$ (Supp. I947): "(a) It shall be unlawful for any person, with intent to interfere with, impair, or influence the loyalty, morale, or discipline of the military or naval forces of the United States-

(I) to advise, council, urge, or in any manner cause insubordination, disloyalty, mutiny, or refusal of duty by any member of the military or naval forces of the United States; or

(2) to distribute any written or printed matter [which does the above]."

${ }_{3}$ Sedition, 43 Time, No. I8, at I7 (May $x$, 1944).

4 Hill, The Tinpot Hitlers, 44 Scholastic, No. I5, at 7 (May 15-20, 1944).

5 Editorial, Libel on Government, Chicago Tribune, p. I4, col. I (Jan. I8, I944).

${ }^{6}$ Wechsler, Sedition and Circuses, 158 Nation 530 (May 6, x944). It was on this basis that the Civil Liberties Union refrained from intervention in the trial after expressing disapproval of the conspiracy charge and reserving the right to object later if essential evidence was not forthcoming. Mrs. Dilling, when informed of the Union's statement, thought this an alibi. "The union is in effect an agency of the New Deal and Communists and is interested only in defending New Dealers and Communists." Chicago Tribune, p. I, col. 8 (April I7, 1944).

7 United States v. McWilliams, 69 F. Supp. 8 I2 (D.C., x946).

${ }^{8} \mathrm{~A}$ copy of the indictment may be found in St. George and Dennis, A Trial on Trial, at p. II4 (x946).

9 Chicago Tribune, p. 8, col. 6 (Jan. 6, I944); Chicago Tribune, p. II, col. 3 (Jan. II, I944).

${ }^{20}$ Reported in N.Y. Times, p. 15, col. 6 (Feb. 26, x944). 
ties, ${ }^{\mathrm{Ix}}$ and as part of a smear campaign against Congress. ${ }^{\mathrm{xz}}$ These and somewhat similar charges made later were responsible for much of the sensationalism with which the trial is generally identified.

Argument on the indictment began in January, the defendants filing numerous demurrers, motions to quash, and a special plea to the jurisdiction of the court. The indictment was attacked for alleged prejudicial surplusage, ${ }^{\mathrm{x} 3}$ duplicity, ${ }^{{ }^{14}}$ and vagueness. ${ }^{15} \mathrm{~A}$ special defense based on the statute of limitations ${ }^{{ }^{6}}$ was asserted, and the jurisdiction of the district court was challenged as to defendants who were non-residents and were not charged in the indictment with being present in the District of Columbia to participate in the conspiracy. On February 28 all such motions were overruled. ${ }^{x}$ The Government had meanwhile filed a voluntary bill of particulars. After the court overruled the defendants' objections to the indictment, argument on this bill began. This argument and further attacks on the indictment consumed another month. Defense counsel argued ${ }^{18}$ that the bill "in every respect fails to set forth, where, when, with whom or under what circumstances" defendants committed acts of conspiracy. One attorney claimed the Government bill had been taken from a book, ${ }^{19}$ and motion was made to strike the bill as inflammatory, apparently because some 25 of its 32 pages were devoted to a history of the rise of Naziism. ${ }^{\circ}$

Other defendants sought a continuance for the duration of the war because, it was said, testimony might be required of government officials which it might not be in the interest of the nation to divulge at the time. ${ }^{2 x}$ Separate trials were sought and the validity of the indictment was attacked because nine government employees had sat on the grand jury.

Ix Editorial, The 3rd Indictment, Chicago Tribune, p. I2, col. I (Jan. 6, 1944).

2 Chicago Tribune, p. 9, col. I (Mar. I4, I944).

${ }_{23}$ Since the acts were not criminal until June 28 , x940, when the statute (supra note 2), was passed, averments as to a movement in Germany prior to that time were alleged to be prejudicial.

34 Though alleging a conspiracy to undermine the morale of the armed forces, the indictment gives rise to an inference that the defendants planned revolution or treason.

ss It was not alleged that any number of the armed forces had in fact received any propaganda material.

${ }^{16}$ The indictment, on its face, charged offenses committed shortly after passage of the statute, prosecution of which was therefore barred by the three-year statute of limitations.

${ }_{77}$ United States v. McWilliams, 54 F. Supp. 79I (D.C., I944).

${ }^{8}$ Chicago Tribune, p. 9, col. I (Mar. I4, 1944). The Chicago Tribune suggested that if the bill was good, the federal practice act needed amending, p. I0, col. I (Mar. Ir, I944).

19 Prince Karl von Loewenstein, Hitler's Germany (I939).

${ }^{20}$ Chicago Tribune, p. 6, col. I (Mar. 2I, I944).

${ }^{2 x}$ Ibid. As an illustration it was pointed out that the government was to call federal communication officials as propaganda experts. The defendants argued that the federal officialswould have to be asked to testify as to the propaganda activities of our allies in order to establish that they were experts. 
On March 27 the court denied I) all demurrers filed or argued; 2) all motions to quash; 3) all motions for a bill of particulars or for a more specific bill than that filed by the Government; 4) all motions filed or argued to strike the Government's bill; 5) all motions for a continuance for the duration; 6) all motions for severance; 7) all pleas in abatement; 8) all motions to inspect the grand jury minutes; 9) any and all motions not specifically enumerated and filed by or on behalf of any of the defendants. ${ }^{22}$ The defendants were ordered to be prepared for trial on April I7.

At this early stage in the proceeding, Justice Eicher had his first of many altercations with defense counsel, which resulted in ejection of Attorney Henry Klein from the court for making what the justice called "a political speech." The court at the time was hearing various motions for additional particulars. Klein had made no such motion and was not arguing that question. He was ruled out of order, persisted in his speech, and was ordered to leave. He refused and the court ordered him removed. Klein was later allowed to return and address the court on condition that he confine his remarks to the matters then before the court. He thereafter moved to postpone the trial, and the court refused to allow the motion to become part of the record.

It took a month to seat and swear in the jury. On April $\mathrm{I} 7$ the case came on for trial, and jury selection was immediately delayed by a new series of defense motions. ${ }^{24}$ Defense counsel repeatedly moved to discharge the entire jury panel on the ground that newspaper and radio publicity had prejudiced its members. The motions were denied. It was also charged that there had been an FBI investigation of all prospective jurors, and that this was "the most serious challenge ... to life and liberty in the District for many years." ${ }_{25}$ The Government admitted a routine examination to determine if any panel members were enrolled in such organizations as the German American Bund or the Silver Shirts, but argued that such examinations were permissible for both sides. Motions to bar the entire panel or such veniremen as had been questioned were denied. Defense counsel also sought postponement of the trial until after the war in order that depositions might be taken from Hitler or Goering, or so that President Roosevelt, Secretary Hull, Attorney General Biddle, and other cabinet members could be called as witnesses. Some attorneys moved to suppress evidence allegedly illegally seized from their clients; others sought to relax the atmosphere of the court room, claiming that drawn blinds, locked doors and the presence of federal marshals turned this into a star-chamber proceeding and made a fair trial impossible. One defense attorney wanted the court stenogra-

22 Chicago Tribune, p. I2, col. I (Mar. 28, 1944).

${ }^{23}$ Chicago Tribune, p. 9, col. I (Mar. I4, I944).

24 N.Y. Times, p. 9, col. I (April 18, 1944); Chicago Tribune, p. I, col. 2 (April I8, 1944); Defendants in War Sedition Trial Enliven Opening by Circus Antics, 23 Newsweek, No. I8, at 34 (May I, I944).

' ${ }^{25}$ Chicago Tribuwe, p. I, col. 3 (April 19, I944). 
pher removed because a member of the stenographers' firm was Jewish. Almost all these defense motions were denied, and consideration of the others was postponed.

These defense motions served further to delay proceedings already delayed by the absence of defendant James Smythe, who was adjudged a fugitive from justice. ${ }^{26}$ On April I 9 he was brought into court after his arrest in upper New York, some forty miles from the Canadian border. He stated that he had received no notification of the trial date, that his mail had been tampered with for months, and that it was "an old racket of the Roosevelt administration, to steal the mail of patriotic Americans." ${ }^{27}$ He demanded a congressional investigation. The Government pointed out that Smythe had fled the jurisdiction under previous sedition indictments. Tried before Justice Eicher for wilfully absenting himself from the trial, he was found guilty, bound by new bail,${ }^{28}$ and his previous bond ordered forfeited.

The court gave its instructions to the venire on April 20. Even this led to argument, many defense counsel charging that Justice Eicher had interpolated the word "insurrection" in his statement of the charge. The court denied using the word, but after some discussion said that if the word had been used it was now withdrawn. Defense counsel all took exceptions. ${ }^{29}$ There was additional argument as to what questions were to be asked the panel and who was to ask them; and eventually it was decided that while attorneys might submit the questions, the court would ask them of the panel. Justice Eicher's ruling that but ten peremptory challenges were to be allowed each side drew additional fire, defense counsel arguing that it was impossible to challenge "one third of a man," and that defendants each ought to have one challenge. Some defense counsel sought ten challenges for each defendant. To support this argument counsel pointed out that their particular clients were so old that if convicted they would die in prison; therefore, it was said, this was like a capital case, and in a capital case each defendant is entitled to ten peremptory challenges. ${ }^{30} \mathrm{On}$ April 2x Rogge mentioned several earlier sedition indictments in argument against accepting, under this indictment, bonds filed under the earlier indictments. This was done in the presence of some prospective jurors, and a group of defense counsel charged that this would prejudice their clients. Eventually the entire group of veniremen in the courtroom at the time was dismissed. ${ }^{3 \mathrm{~K}}$

Selection continued from the remainder of the venire, and on April 26 twelve

${ }^{26}$ N.Y. Times, p. 9, col. I (April I8, I944).

${ }^{27}$ N.Y. Times, p. x, col. r (April 20, 1944).

${ }^{28}$ Bail was fixed at $\$$ ro,ooo after the court denied a government request that it be fixed at \$100,000. Chicago Tribune, p. I, col. 3 (April 20, I944). Smythe's bond had previously been fixed at \$1,000. N.Y. Times, p. I4, col. 2 (April 22, 1944).

${ }_{29}$ N.Y. Times, p. 6, col. 2 (April 2I, 1944); Chicago Tribune, p. I, col. 8 (April 2I, I944).

${ }^{30}$ Chicago Tribune, p. 2, col. I (April 2I, 1944).

${ }^{31}$ N.Y. Times, p. I4, col. 2 (April 22, 1944); Chicago Tribune, p. I, col. 8 (April 21, 1944). 
prospective jurors were seated. By the next day, when each side had exercised over half of its peremptory challenges, the jury seemed on its way to completion.

At the next trial session, however, jury selection was halted while the Government sought an order directing attorney James Laughlin to show cause why he should not be held in contempt of court. The attorney was charged with presenting a number of irrelevant motions, and with making statements not in good faith but in furtherance of a malicious scheme to create news stories which would prejudice prospective jurors, so as to disqualify them and thus interfere with the trials. ${ }^{32}$ Among the statements and motions cited by the Government as having been made by Laughlin as part of his scheme were a motion to subpoena Admiral Kimmel and General Short, ${ }^{33}$ and a petition to impound the records of B'nai B'rith, the Jewish Anti-Defamation League, the Nonsectarian Anti-Nazi Society, Friends of Democracy, and the Communist party to show these groups had engaged in a conspiracy to besmirch the names of MacArthur, Bricker, Nye, Wheeler, Vandenberg, Fish, Hoffman, and Rankin by connecting these people with defendants. ${ }^{34}$

Also cited were Laughlin's motions to subpoena Ford and Lindbergh as defense witnesses, ${ }^{35}$ his letter to President Roosevelt asking the President to stop the trial because of the "wave of hostility and bias toward the Jewish race" which the trial would create, ${ }^{36}$ and the affidavit of bias and prejudice filed by him seeking to disqualify Eicher on the ground that the judge had been promised a higher judicial post by the President if he were to secure a conviction at the trial. ${ }^{37}$ Laughlin was tried before another judge, found guilty of conternpt and fined $\$ 55^{0} .{ }^{38}$ On appeal the ruling was affirmed. ${ }^{39}$ The sedition proceedings were, however, suspended until the contempt had been tried. The effect of all this was to require another jury impanelling, for the veniremen from whom the jury was to be selected were "April term" veniremen and could be used for purposes of selection only until May 2..40 The Government had petitioned for the "show cause" order on May I, and the contempt decision was handed down on May Io.

${ }^{32}$ N.Y. Times, p. I, col. 4 (May 2, I944). Laughlin called the Government petition "a deliberate attempt to throttle freedom of speech and freedom of the press." Chicago Tribune, p. 8, col. 3 (May $x$, r944). Another defense attorney thought it "a vicious attempt to intimidate counsel." Chicago Tribune, p. I, col. I (May 2, I944).

33 Chicago Tribune, p. I, col. 2 (Feb. 3, I944).

34 Chicago Tribune, § I, p. I3, col. I (April 23, I944).

${ }^{35}$ Chicago Tribune, p. 8, col. 3 (April 24, 1944).

${ }^{36}$ Chicago Tribune, p. II, col. 2 (April 25, I944).

37 Chicago Tribune, p. Ir, col. 2 (April 27, 1944).

${ }^{38}$ N.Y. Times, p. 2I, col. 5 (May Ir, I944).

${ }^{39}$ Laughlin v. United States, 151 F. 2d 28I (App. D.C., 1945), rehearing den. 151 F. 2d 285(App.D.C., r945), cert. den. 326 U.S. 777 (r945).

${ }^{\circ}$ N.Y. Times, p. 2I, col. 6 (April 28, I944); Chicago Tribune, p. I2, col. 7 (April 28, 1944). 
The trial resumed on May II, its cast of defendants lessened by one, ${ }^{4 I}$ and moved ahead with dispatch as compared with the previous proceedings. Pro-. ceedings were delayed by repeated motions to question the prospective jurors as to their belief in free speech and as to whether they would be unduly prejudiced if it were shown that defendants believed in pro-Nazi statements. These were denied. ${ }^{42}$ And on May I2 Ira Koehne, a defense attorney, was held in contempt and fined \$50 when he challenged "ro/2gth's" of "the upper portions of the anatomy" of three prospective jurors. ${ }^{43}$ This was in protest against the court's ruling that the entire group of defendants was to have only ten peremptory challenges, which required defendants to exercise their challenge in groups of three. Before the jury was sworn, a motion seeking sanity tests for all defendants was made and rejected. Thereupon other defense attorneys moved that the prospective jurors be disqualified on the ground that the motion would cause undue prejudice. This too was rejected. On the I6th a jury was selected, sworn, and seated. Again defense counsel urged delay, arguing the impossibility of a fair trial in wartime. All such motions were denied and the next day the Government prosecutor made his opening statement to the jury.

That day's proceedings "approached the proportions of a riot." 44 It took Rogge nearly three hours to make his statement, and wild disorder broke out almost from the moment he began. ${ }^{45}$ After order had been restored by the federal marshals, Rogge began again. He completed a few sentences and again was interrupted by uproar from deféndants and their counsel, apparently because of his statements that defendants "intend to use the same methods the Nazis had used." There were shouts of "mistrial," "does this court believe in the Constitution?" and so on. Thereupon Rogge suggested to the court that he be permitted to speak without interruption and that defense attorneys note their objections and make them after he had finished. Vigorous protests by defense attorneys led once more to the use of the marshals, and upon adoption of Rogge's suggestion the defendants loudly whispered "this is Moscow." The court ruling had little effect, for several attorneys continued to offer objections throughout Rogge's presentation of his statement. ${ }^{46}$ As Rogge continued he was interrupted from time to time by boos, catcalls, and remarks such as "that's not true," "that's a lie." When the Government prosecutor had finished, one defense counsel after another rose to demand a mistrial or expunging of Rogge's statement from the record as irrelevant to the indictment and designed to inflame the jury. The motions were denied.

4 Garner had died meanwhile. N.Y. Times, p. 21, col. 5 (May 5, 1944).

${ }^{4}$ N.Y. Times, p. 2I, col. 5 (May II, I944) and p. II, col. I (May I6, I944).

${ }^{43}$ N.Y. Times, p. 5, col. 5 (May I2, 1944); Chicago Tribune, p. 3, col. 3 (May 12, 1944).

44 Chicago Tribune, p. 5, col. 4 (Aug. 8, 1944).

45 This was due, apparently, to defense objections to the presence of a Government witness. Chicago Tribune, p. 2, col. I (May 18, I944).

${ }^{6}$ N.Y. Times, P. I, col. 2 (May I8, I944). 
The defendants' opening statements were completed several days later, again with some difficulties. The court had ruled that defense attorneys would be limited to thirty minutes in their opening remarks, though more time would be granted if need were shown. Several defense attorneys protested, and defense attorney Klein was fined $\$ 200$ for continuing to argue after Eicher had declared him out of order. Jones, who acted as counsel pro se, was fined \$Ioo for similar objections when he said, "This is persecution not a prosecution. I wish to take exception to your arbitrary - " 47 In effect the several defendants denied guilt, protested their innocence and patriotism, and denounced the proceedings as a "travesty on justice" $4^{8}$ or as the result of pressure by secret Jewish or Communist elements.49

A few sensational events were yet to occur. On July 5, I944 Attorney James Laughlin was dismissed from participation at the trial after he had filed a petition in the House of Representatives seeking impeachment of Justice Eicher. ${ }^{50}$ The petition charged Justice Eicher with favoring the Roosevelt administration and thus denying a fair trial to the defendants, that Eicher had been promised a higher judicial position in the event he secured a conviction, and that he was using his office for political purposes. ${ }^{x}$ Laughlin's petition for a writ of mandamus to reinstate himself as counsel was denied..$^{.2}$

Attorney Henry Klein absented himself from the trial and refused to return, claiming that he had been intimidated and was unable to defend the rights of his client. ${ }^{53} \mathrm{He}$ was returned from New York after a hearing on a warrant for his removal to Washington. At the hearing Klein stated he did not want to return because "I don't want to be tossed into a cell and murdered," and referred to "an odorless, tasteless poison which is known to those on the inside of the present administration." ${ }^{54} \mathrm{He}$ was sentenced to ninety days in jail by Judge Eicher after having refused an alternative of ten days in jail and suspension of the

47 N.Y. Times, p. 77 , col. 3 (May 23, I944); Chicago Tribune, p. 3, col. I (May 23, I944). Jones's appeal of the contempt conviction was denied. Jones v. United States, r $^{\mathrm{I}}$ F. $2 \mathrm{~d} 289$ (App. D.C., I945).

${ }_{4}^{8}$ Remarks by L. Dennis when told he would not be allowed to show a world conspiracy by Communism, to which the government was linked. N.Y. Times, p. I7, col. 3 (May 23, I944).

49 Klein, counsel for the defendant Sanctuary, stated he would show that the prosecution was initiated to "cover the enemies of the Government" and to protect the Communists. Attorney Dilling, representing Mrs. Elizabeth Dilling, stated that his client's defense would show B'nai B'rith to be the force behind the indictment as part of a "world wide anti-Christian, pro-Communist secret Jewish fraternal society" against civil liberties and the "gentile majority." N.Y. Times, p. 17, col. 3 (May 23, r944). He also stated that his client was not antisemitic. Chicago Tribune, p. 3, col. I (May 23, 1944).

so N.X. Times, p. 5, col. 6 (July 6, I944); Chicago Tribune, p. 7, col. 4 (July 6, I944).

sx Chicago Tribune, $\$$ x, p. 2, col. 3 (July 2, I944).

${ }_{52}$ Laughlin v. Eicher, I45 F. 2d 700 (App. D.C., 1944).

53 N.Y. Times, p. 5, col. 6 (July 6, 1944); Chicago Tribune, p. 2I, col. I (July 7, I944).

54 Chicago Tribune, p. 2, col. 3 (Aug. 8, I944). 
remainder of his sentence if he would resume his defense of Sanctuary. ${ }^{55}$ On appeal, Klein's conviction was reversed..$^{60}$

By the middle of July three of the defendants had been severed from the case. On July $1_{3}$ Government motions to sever the cases of Baxter and Noble were granted, ${ }^{57}$ the former because his partial deafness made it impossible for him to understand the testimony, the latter because of his obstreperous conduct in the courtroom. Noble had been represented by Laughlin, and when that attorney was dismissed, $M$. Bischoff was appointed to replace him. Noble objected to this, and at every available instance during the trial jumped up to repudiate Bischoff's services. On the r4th defendant James True, who had been ill, was ordered severed, ${ }^{58}$ reducing the number of defendants to twenty-six. It remained at this number for the rest of the trial. Despite these more enlivening examples the trial, with the introduction of testimony, settled down to a grim and bitter technical fight and the proceeding degenerated to an "interminably repeated pattern."

"The prosecution presents a bit of evidence-either statement from a witness or the offering of a document.

" 'We object' shout anywhere from two or three to a dozen defense attorneys, whereupon follows half an hour to half a day in their outlining of objections.

" 'Objection denied,' finally rules the court.

“ 'Exception,' demands some defense lawyer.

" 'Exception may be noted!'

" 'For all defendants,' cry a few more defense counsel.

"'For all defendants,' rules the court and the rigamarole starts all over again." $" 59$

On November 30, I944 Chief Justice Eicher died of a heart attack, and a week later a mistrial was declared. ${ }^{60}$ The proceedings were never reopened and on December 2, 1946 the indictment was dismissed. ${ }^{6 x}$ So it may be said that the

${ }^{35}$ N.Y. Times, p. 15 , col. 4 (Sept. 30, 1944).

${ }^{56}$ Klein v. United States, I5I F. 2d 286 (App. D.C., 1945) (on the reasoning that Klein's refusal to return was not in the presence of the court or so near thereto as to be punishable by summary contempt proceedings).

s7 N.Y. Times, p. I3, col. 2 (July I4, I944); Chicago Tribune, p. II, col. I (July 14, 1944).

${ }^{88}$ N.Y. Times, p. 9, col. 8 (July 15, 1944); Chicago Tribune, p. 15, col. I (July 15, 1944).

59 N.Y. Times, \& 4, p. 6, col. 5 (Oct. 29, I944). Another reporter wrote that "The trial ... has lapsed into a routine of dreary legalistic fencing. What was once the best show in town outside the monkey house of the National Zoo has been deserted by the public." Chicago Tribune, p. 4, col. I (Aug. 8, I944). This "desertion" is reflected in the press coverage of the trial. By late October the number of reporters regularly covering the trial had shrunk from forty to four. N.Y. Times, $\$ 4$, p. 6, col. 5 (Oct. 29, 1944).

60 The mistrial was declared on Dec. 7 , 1944. Before its decision the court polled the defendants as to their willingness to continue under a new judge. One defendant, Dennett, wished to continue. N.Y. Times, p. 14, col. 3 (Dec. 8, 1944).

or Note 7 supra. 
trial ended as a monument to the success of a strategy of delay. Of the Government's 4,000 exhibits but I,000 had been admitted; of its I00-odd witnesses but 39 had been heard. Even so, the record at the date of Justice Eicher's death totaled more than three million words in almost $18, \infty 00$ pages, and weighed more than 150 pounds. Seven defense attorneys had been fined a total of $\$ 1,220$; one defendant had died; three had been severed; one attorney had been discharged from the case; and another had run away. The proceedings had cost the government over $\$ 60,000$. These may, to some, be considered the results of the trial. The outcome of the trial disappointed many people who were irritated and angered by defendants' views, their apparent contempt for the judicial process, and the techniques used by defense counsel. The history and nature of the proceedings, however, themselves suggest the causes for its failure.

At the inception of the proceeding no one thought it would last as long as it did, the usual estimate for the time of the trial being two or three months. Early, however, it became apparent that the defendants, or at least some of them, would maneuver to delay..$_{2}$ As the success of their tactics became clear, estimates of the time required to conclude the case grew until Rogge admitted: "It's just impossible to estimate the length of this case. All our estimates seem now like fairy tales." 63

Obviously dilatory tactics received some condemnation from the court, and by punitive measures attempts were made to avoid delay. On successive days, $\$ 200$ contempt fines were levied on Klein for obstructing the trial by dilatory cross examination, ${ }^{64}$ Dilling for repetitious tactics, ${ }^{65}$ and Laughlin for insisting on a line of questioning previously banned. ${ }^{66}$ At other times various defense counsel were warned against frivolous objections, repetitious motions, ${ }^{67}$ or long pauses between questions. The trial judge's control of proceedings from this point of view might be questioned; it could be argued that there was more laxness in this respect than the situation warranted. This might have been due to a deliberate effort to maintain "judicial impartiality" by a man whose friendly feelings toward the administration had been sharply and critically pointed out in highly publicized statements by various defendants. Indeed some observers of the trial felt that Justice Eicher was bending backward in his effort to insure a fair trial. The trial judge of course has and ought to have great discretion in this regard. It nevertheless seems clear that contempt fines came too sporadically to be effective as a means of controlling procedure. The court

62 Lahey, Fascism's Day in Court, rro New Republic 759 (June 5, I944); Defendants in War Sedition Trial Enliven Opening by Circus Antics, 23 Newsweek,. No. I8, at 34 (May I, 1944).

${ }_{33}$ Sedition, 44 Time, No. 9, at 15 (Aug. 28, 1944).

64 N.Y. Times, p. 24, col. 2 (June 28 , I944).

65 N.Y. Times, p. 9, col. 4 (June 29, 1944).

${ }^{66}$ N.Y. Times, p. I5, col. 7 (June 30, 1944).

${ }_{67}$ N.Y. Times, p. 36 , col. 3 (June 27 , I944). 
also adopted a procedure whereby $\mathrm{r}$ ) all objections made to any document would apply to future evidence of the same kind and 2) all attorneys would be considered as having made an objection voiced by any one attorney unless notice to the contrary was given. ${ }^{8}{ }^{8}$ But these attempts at procedural streamlining seem to have been forgotten almost as soon as promulgated.

Any sort of organized procedure was made impossible by what seemed at times a complete lack of respect for the court. Thus attempts to procure smooth handling of the trial were frustrated, and in many situations collateral questions were raised which had to be handled while the main proceedings were temporarily halted. Further, persistent attempts were made to becloud the issue involved by picturing the trial as a political or ethnological fight. Appeals were made to Congress to protect the defendants against administrative vindictiveness and early in the proceedings Mrs. Dilling sent to various legislators a letter suggesting that the trial was an attempt to purge the Congress. ${ }^{69} \mathrm{Mrs}$. Dilling's attorney later petitioned the Senate to send a delegation to the trial to insure fairness in the proceedings, ${ }^{70}$ and as previously mentioned, a petition seeking impeachment of the presiding judge was filed in the House of Representatives. Whatever the motives of the various defendants and their counsel in making such charges, the effect was to insure wide publicity and perhaps to delay the trial by prejudicing prospective jurors.

The sweeping nature of the charges of the indictment and the varied alleged connections of the defendants with the alleged conspiracy tended to require a large amount of prosecution evidence. To prove its case the Government proposed to introduce great numbers of exhibits and numerous witnesses. With this array of proposed evidence the possibility of legitimate delay is clear; and delay becomes highly probable when, as actually occurred, at least some of the defendants undertook to fight the introduction of each item of evidence.

The very number of defendants was of itself a delaying factor. For example, the court's ruling that ten peremptory challenges would be allowed the thirty defendants necessitated the formation of defendants into groups of three. Defendants refused or were unable to form such groups and the court arbitrarily created them. The groups so formed were not, however, able to agree on how their challenge was to be exercised and it was therefore necessary to keep shifting the defendants around until at length a group could be formed which was able to challenge. This, of course, caused delay.

On July 28, x944 the Washington Post in an editorial asserted that "where the issues are complicated and defendants who have not been browbeaten stand on their democratic rights, a trial involving more than two dozen individuals is

${ }^{68}$ N.Y. Times, p. Ir, col. 4 (June 6, I944).

${ }^{69}$ Chicago Tribune, p. 9, col. 2 (Mar. I4, I944). No public reaction by any congressman was reported. Chicago Tribune, p. 26, col. 5 (Mar. 15, I944).

${ }^{70}$ N.Y. Times, p. 2r, col. 8 (May 4, I944). This petition was rejected unanimously by a sub-committee of the Senate Judiciary Committee who charged that even the appeal to the legislature "smacks strongly of an attempt to intimidate or influence the court." 
almost certain to be a fizzle." By "democratic rights" the editorial writer apparently refers to the exclusionary rules of evidence. For once the introduction of testimony began it was around these rules that the trial fizzled. Defense counsel's arguments on the evidence were castigated by one observer as an effort to keep the jury from hearing the case, and as previously pointed out there were hints that defendants were trying to stall the trial until the end of the war. But another reporter in the New York Times praised the objections of defense counsel as a fine example of democracy in action, particularly since more than twenty of the twenty-nine defense attorneys were court-appointed, unpaid, and thus economically injured by any delay in the proceedings. It certainly could not be argued that defense counsel had no right to object to evidence, though if this were deliberately done to delay it would probably be punishable. As one of its officers, an attorney is to aid the court in its determination of a case, but he has also a duty to protect his client by objecting to the introduction of irrelevant or inflammatory material. In accomplishing the latter task counsel also carries out the former, on the assumption that the exclusionary rules aid in the judicial ascertainment of the truth. However, the possibilities of delay inherent in the rules are greatly enhanced if there are numerous defendants. The defendants might have minimized delay by a union of strategy and by the use of a few attorneys to represent all. Had this been done, however, the unification of the defendants in the alleged conspiracy might have been suggested to the jury, which the Government was supposed to have the burden of proving. Thus defense counsel bickered, fought, and objected to each others' statements, and no doubt defendants had the right to adopt these tactics.

The real "villain in the piece" may therefore be the rules of evidence. If based on reasonable assumptions, they may be justified even though they allow a result such as that which occurred here. This may be part of the price we pay for a fair trial even in situations where those seeking the benefit of the rules seek also to destroy that for which the rules stand.

It can reasonably be asked why the Government, at least when defense strategy became clear, did not seek to sever the various cases and move against the defendants individually. Possibly the Government's case against some of the defendants rested on its ability to prove the conspiracy, but it is doubtful whether a result in which some of defendants might have been convicted and others not prosecuted would have been of less value than the fiasco which actually occurred.

\section{SOLDIERS' AND SAILORS' WILIS: A PROPOSAL FOR FEDERAL LEGISLATION}

It is said that Julius Caesar, as a temporary measure, first extended to the soldiers in his legions the privilege of disposing of their personal property by informal testament.. By the time of Trajan it had been extended to naval per-

× Swinburne, Testaments and Last Wills, pt. I, §§ I0, I2, I4 (7th ed., I793). 